\title{
RÉGI PÉCSI ISKOLÁK ALBUMA 1868-1948
}

\author{
NAGY ADRIENN \\ a Pécsi Tudományegyetem Bölcsészettudományi Kar Oktatás és Társadalom \\ Doktori Iskolájának doktorandusz hallgatója \\ moli7@t-online.hu
}

2009. május 19-én került sor a pécsi Janus Pannonius Várostörténeti Múzeum Bezerédy Gyözö termében Régi pécsi iskolák albuma 1868-1948 címmel megrendezett interaktív iskolatörténeti on-line adatbázisának bemutatójára. A digitális albumot - egyszersmind egy információkban is rendkívül gazdag adatbázist - készítöi Pásztor Andrea (történész, muzeológus), Pusztafalvi Henriette (PTE ETK Egészségfejlesztési Tanszék föiskolai adjunktusa, az óvodatörténeti fejezet készítöje) és lektorai Kéri Katalin (PTE BTK Nevelés- és Művelődéstörténeti Tanszék egyetemi docense) és Rozs András (nyugalmazott levéltáros) mutatták be.

A bemutató résztvevőit egy virtuális tárlatvezetés során - rendkívül alapos kutatómunka során összegyüjtött fotók segítségével - próbálták elkalauzolni a korabeli pécsi iskolák világába. A pécsi iskolákról készült digitális album elsődleges forrásbázisául a Janus Pannonius Múzeum Új- és Legújabb Kori Történeti Osztályának fotói és nyomtatványai szolgáltak. A magyar és angol nyelvủ internetes fotóalbum 2007-ben a Nemzeti Kulturális Alap támogatásával készült el először CD formájában, ám immáron már a világhálón is ingyen elérhető bárki számára (http:// www.emu.jpm.hu/). Bár az adatbázist készítői elsősorban a régi pécsi iskolákat és óvodákat bemutató digitális fotóalbumnak szánták, ahogy ezt a címe is előrevetíti, ám végül sokkal több lett annál. Ugyanis amellett, hogy készítői aprólékos kutatómunkával összegyüjtötték és digitalizálták a korabeli fényképeket, egyben minden iskoláról rövid leírást is készítettek, oly módon, hogy a korabeli iskolatípusokról, oktatási törvényekről, rendelkezésekről és az oktatáspolitikát fémjelező jeles személyiségekről egyaránt jól áttekinthető és információban gazadag képet kaphatnak mindazok, akik ellátogatnak a honlapra vagy megvásárolják a CD-jét.

Mivel Pécsett 1868 és 1948 között minden iskolatípus képviseltette magát, így gyakorlatilag a fényképalbum és a hozzá kapcsolódó szöveges részek megtekintésével szinte teljes képet kaphatunk arról, miként alakult a korabeli Magyarország iskolarendszere és oktatáspolitikája és egyszersmind betekintést nyerhetünk Pécs város történetébe is. Az iskolatörténet mellett feltétlenül érdemes kiemelni Pusztafalvi Henriette által készített óvodatörténeti részt is, amely amellett, hogy összefoglalja a kisdedóvók történetét, egyben sok érdekességgel is szolgál a sokszor az is- 
kolák mellett feledés homályába vesző, az iskolás kort megelőző intézményes oktatásról, nevelésröl.

Rendkívüli előnye ennek a digitális albumnak (honlapnak) - a képekhez csatolt szöveges ismertetők rövid ám annál lényegretöröbb megfogalmazása mellett egyrészt, hogy nagyon jól és gyorsan áttekinthető, így könnyen használható mindenki számára, másrészt pedig az, ha egy-egy iskolához kapcsolódó szöveges részt olvasva elbizonytalanodnánk, például az adott iskolatípusnak a korszakban betöltött szerepét illetően, további információkat találhatunk különbözö linkek alatt. Ugyanis az óvoda- és iskolatörténethez kapcsolódik még egy kislexikon (amely alatt az egyes iskolatípusoktól a tankerületek müködéséig szinte mindenről találunk egy rövid ismertetőt), egy arcképcsarnok híres pécsi pedagógusok és a pécsi oktatásért eredményesen tevékenykedő személyek képeivel és életrajzával, egy törvénytár, amely segít eligazodni a korszak oktatási rendszerét befolyásoló törvények útvesztöiben, egy bibliográfia, amely minden iskolatörténet végén közli a felhasznált forrásokat és nem utolsó sorban egy térképtár, mellyel az iskolák helyét egy rendkívül izgalmas interaktív térkép segítségével találhatjuk meg. Így mindezeknek köszönhetően - egy amúgy rendkívül ízlésesen megtervezett honlapon - az iskolatörténetben kevésbé járatos érdeklődők is egyszerüen és viszonylag gyorsan képet kaphatnak egy-egy pécsi oktatási intézmény történetéről. Az adatbázis jelentősége és egyben nagyszerúsége - amellett, hogy a neveléstudományi források tekintetében a maga nemében páratlan újdonságnak számít -, hogy a rendkívül jól eltalált nyelvezetének és történetileg is pontos adatoknak köszönhetően egyszerre szól a téma iránt pusztán csak érdeklődőknek és az oktatástörténettel foglalkozó kutatóknak. A kutatók szempontjából talán egyetlen hátrányát lehet megemlíteni - ha ez egyáltalán hátránynak nevezhetö - mégpedig azt, hogy a fényképeket ugyan fel lehet nagyítani, de sem a honlapon, sem a CD-n lévő képekről nem lehet másolatokat készíteni.

A régi pécsi iskolák albuma közép és felsőoktatásban egyaránt jól hasznosítható, hiszen segítségével nemcsak színesebbé, élvezetesebbé, hanem információkban gazdagabbá is tehető egy-egy óra.

Az adatbázis készítői az általuk kitüzött céloknak - hogy szöveges és a képi illusztrációkon keresztül közérthető formában mutassák be az egyébként szerteágazó oktatástörténetet - maradéktalanul megfeleltek, sőt mi több túl is teljesítették azt. Hiszen ezáltal nemcsak egy újfajta iskolatörténeti forrásbázissal gazdagodtunk, hanem maga az iskolatörténetet - amely napjainkban a neveléstörténetnek igencsak elfeledett és kevésbé népszerü tudományterülete - is egy egészen új és izgalmas megvilágításba került. Készítői tervezik a már elkészült korszak iskolatörténetének további forrásokkal való bővítését (ez egyben másik hihetetlen nagy előnye ennek a digitális adatbázisnak, hogy bármikor frissíthető), illetve az államosítás utáni korszak oktatástörténetének elkészítését is. 